\title{
Lightning protection of tall buildings with glass façade architecture
}

\author{
Satheesh Jacob \\ Excel Gateway Limited \\ United Kingdom \\ www.excelgateway.com \\ satheesh.jacob@excelgateway.com \\ Professor WH Siew \\ University of Strathclyde \\ Glasgow, United Kingdom \\ www.strath.ac.uk \\ wh.siew@strath.ac.uk
}

\author{
Ghalib Azam \& Adarsh Raina \\ Ramboll Limited \\ United Kingdom \\ www.rambol.com
}

\author{
Ziyang Peng \& HK Agyemang \\ University of Strathclyde \\ Glasgow, United Kingdom \\ www.strath.ac.uk
}

\begin{abstract}
In the recent times, many buildings have been constructed using glass facade architecture with metallic grid support. For buildings with glass-façade, the lightning current path may flow through the metallic grid of the façade rather than the structural reinforcement depending on the architectural design. This, therefore results in the metallic grid of the glassfaçade being subject to the full lightning current. Integration of the Lightning Protection System (LPS) with the building façade will ensure safety. This paper reports the findings of the early stage research conducted to investigate the effectiveness of the present implementation of the BS EN Standard on Lightning Protection System for tall buildings with glass façade architecture. The results show that the current lightning protection system used in tall buildings with glass facade do not protect the metallic frames of the glass facade as they are not continuously bonded to earth nor designed to carry lightning current. There is the need to develop a comprehensive lightning protection system for tall buildings with glass facade architecture.
\end{abstract}

Keywords-lightning; glass facade; style; architecture; protection; tall buildings; standard

\section{INTRODUCTION}

Nowadays buildings with glass facade architecture are on the increase as they offer thermal insulation, solar control, better safety, security and fire resistance. Glass facades are mainly used in buildings for curtain walls. The glass is supported using frames, usually made of aluminium. There are other framing materials such as steel, PVC- U, timber. The use of composite frames by the manufacturer allows the advantage of having both materials, some common combinations are Aluminium-PVC U, Stainless Steel- Aluminium.

The down conductor system of tall buildings are usually steel columns or concrete reinforcements. In compliance with the current IEC/EN standards the frames of the glass facade and other conducting components are bonded to the down conductors to achieve equipotential bonding and the expectation is that lightning current conducted through the frames takes the path to ground using the down conductor system because of the bond.

The hypothesis is that the lightning current path will flow through the outer membrane of the structure rather than through the inner components due to the "skin effect". This research mainly focuses on the anomaly in the current standard and design practice and intends to throw light on the need to mitigate the risk.

\section{GLASS FAÇADE ARCHITECTURE}

The building envelope is an important consideration by architects. One of the main components of a building envelope is the facade. It is defined as an aluminium framed wall containing infill of cladding materials such as glass, stone or metal panels. The purpose of a facade in a building is to provide a good environment, exclude the weather and retain its look throughout the life. There are two types of building facade, they are single skin and double skin facade as in Fig. 1. The double skin facades are increasingly used nowadays as it has more advantages compared to the single skin facade.

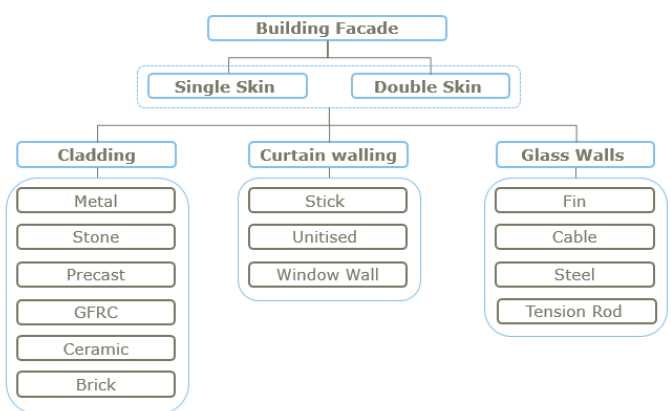

Figure 1. Types of building façade [1] 
There are three types of curtain walling systems, they are Stick curtain wall, Unitized curtain wall and Panelized curtain wall.

\section{A. Stick Curtain Wall}

The stick curtain wall system is assembled piece by piece (sticks) on site using framing members and glass. The vertical frame is called the mullion and the horizontal frame is called the transom as in Fig. 2.

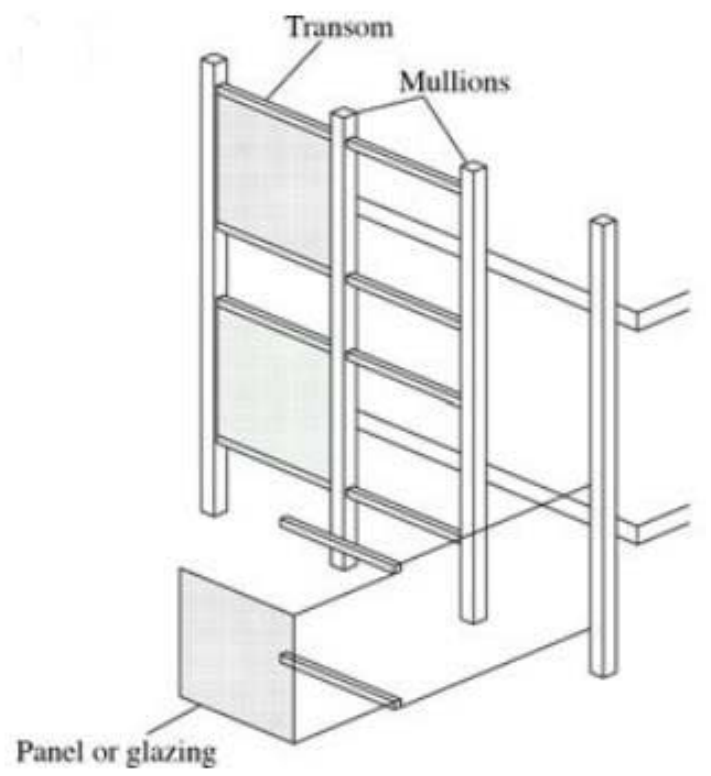

Figure 2. Stick Curtain Walling [2]

\section{B. Unitized Curtain Walling System}

In unitized curtain walling, the glazing panels are preassembled in the factory and brought to the site. They consist of a metallic frame mainly aluminium that accommodates one or more layers of glass. These units are connected to the building at every floor slab using brackets as in Fig. 3.

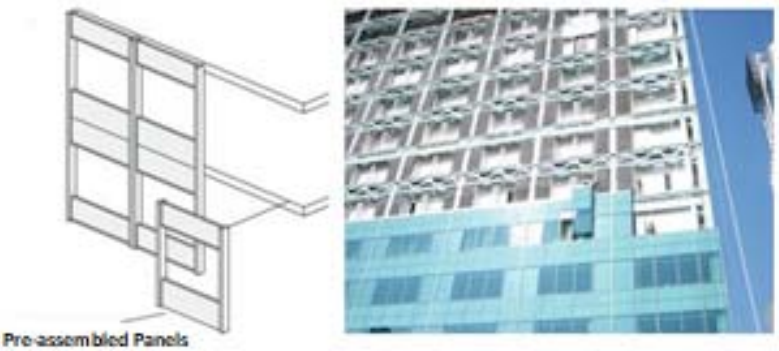

Figure 3. Unitized Curtain Wall [2]

\section{Panelized Curtain Walling System}

Panelized curtain wall systems are like the unitized curtain wall except they have larger modules that can be used directly on the structure. The frame with insulation is made of aluminium or steel. The only difference between unitized and panelized systems are the dimensions and weight which is why it is also termed as window walling systems as in Fig. 4.

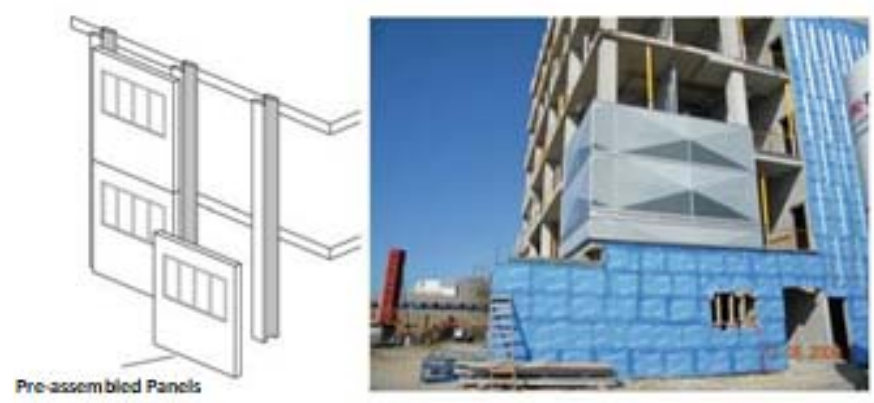

Figure 4. Panelized Curtain Wall [2]

\section{METHODOLOGY}

A model building of dimensions 90m(height) $x 20 \mathrm{~m}$ (length) $\times 15 \mathrm{~m}$ (width)is taken into consideration. And typical window dimensions of $4.2 \mathrm{~m}$ (height) $\times 1.45 \mathrm{~m}$ (width) with slab to slab height of $4.2 \mathrm{~m}$ and 200 sqm of occupied area. The building is a tall building with glass facade profiles bonded to the weight bearing element of the structure.

Equation (1) from the BS EN 62305-1 Annex B is used for lightning current evaluation in this study.

$$
i=\frac{I}{K} \times \frac{\left(t / T_{1}\right)^{10}}{1+\left(t / T_{1}\right)^{10}} \times \exp \left(-t / T_{2}\right)
$$

Where

$$
\begin{aligned}
\mathrm{I} & =\text { the peak current } \\
\mathrm{K} & =\text { the correction factor for the peak current } \\
\mathrm{t} & =\text { the time } \\
\mathrm{T} 1 & =\text { the front time constant } \\
\mathrm{T} 2 & =\text { the tail time constant }
\end{aligned}
$$

The first positive impulse lightning current is used with a peak current of $150 \mathrm{kA}, 0.93$ correction factor for the peak current and a front and tail time constants of $19 \mu \mathrm{s}$ and $485 \mu \mathrm{s}$ respectively.

The model consists of two cages bonded together at their vertical sides as in Fig. 5.

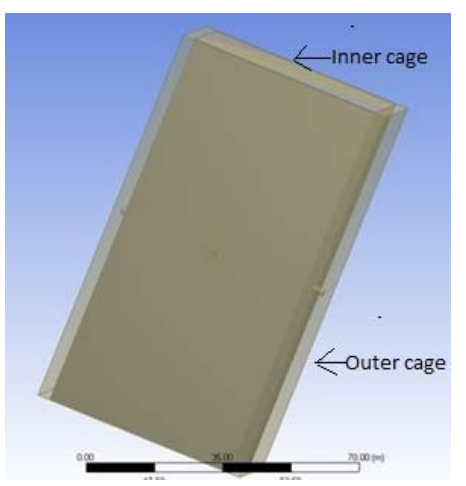

Figure 5. Proposed Design Model [3]

The inner cage represents steel columns or concrete reinforcements used as natural down-conductors in the LPS of tall buildings. The outer cage represents the conductive frame of the glass façade profiles for a tall building with glass façade architecture. The inner and outer cages are bonded together to 
represent the bonding of the mullions and transoms of the glass façade structure to the natural down-conductors of the building.

Lightning current strikes at different points on the building including the sides of the building are simulated to determine the path of lightning current for different grounding conditions. The grounding of the inner steel cage is a representation of present lightning protection procedure as per BS EN 62305. This represents the connection of the natural down-conductors of tall buildings to the building's earth- termination system with the façade frames bonded to the down-conductors. The grounding of the outer façade structure is to allow for the testing of the effectiveness of the current implementation of the lightning protection standard due to the "skin effect". The simulation of side flashes is due to the conductive nature of glass façade frames and the natural susceptibility of tall buildings above $60 \mathrm{~m}$ to lightning side flashes.

All simulations in this research are carried out using the ANSYS ${ }^{\circledR}$ Academic Research, Release 16.1 software, the component modelling within ANSYS MAXWELL is the Electromagnetic Suite. In the ANSYS ${ }$ Mechanical application, structural steel is assigned to the inner cage to represent the steel used as natural down-conductors in tall buildings. Aluminium alloy is assigned to the outer cage since the mullions and transoms of glass façade profiles are usually constructed using aluminium. Copper alloy is used to establish the bonding between the vertical surfaces of the steel and aluminium cages and the air is used to fill up the control volume that envelops the entire model.

\section{ANALYISIS}

For the purpose of this research two scenarios are studied by using the model of the building. Two attachment points are chosen for the lightning current: firstly, at the top into the main frame and secondly into the top of the façade at the edge of the building. The main lightning protection system consists of air terminal on the roof, the reinforcement rods that form the down conductors and the mesh foundation grounding that form the earthing. The external façade is bonded on to the reinforcement rod at every second floor. The façade frame is also grounded to the building foundation which forms the common earth. The frames are assumed to be electrically continuous.

The simulations are run on ANSYS MAXWELL, and the values of current density are obtained. For each case the amount of current that flows through the frame is calculated by the product of the current density and the cross-sectional area for each bond-conductor between the façade and the mainframe. The cross- sectional area of the frame is the same for all the cases. In all the simulations, the current density is found to be maximum at the attachment point and then it decreases along the structure.

\section{A. Scenario I}

In the first scenario, the current is injected into the main frame at the top of the building at the air terminal as illustrated in the Fig. 6.

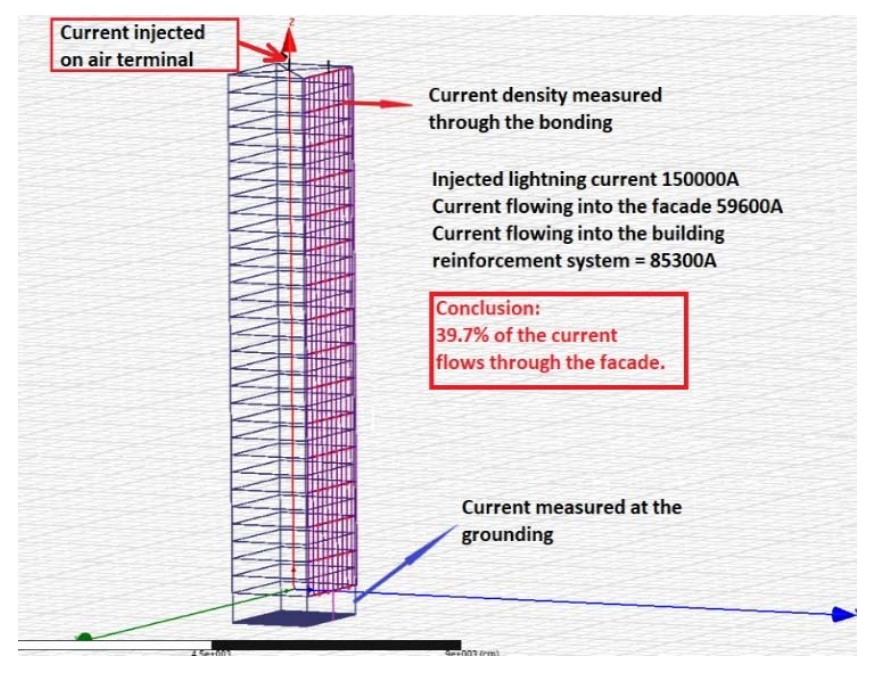

Figure 6. Current injected on main frame as in Scenario 1 [3]

TABLE I. SIMULATION RESULTS FOR SCENARIO 1

\begin{tabular}{|c|c|c|c|c|c|}
\hline $\begin{array}{c}\text { Number } \\
\text { of } \\
\text { bonding } \\
\text { from } \\
\text { rooftop } \\
\text { to earth }\end{array}$ & $\begin{array}{c}\text { Current } \\
\text { density } \\
\text { for the } \\
\text { first } \\
\text { bonding } \\
\text { (A/m2) }\end{array}$ & $\begin{array}{c}\text { Current } \\
\text { density } \\
\text { for the } \\
\text { second } \\
\text { bonding } \\
\text { (A/m2) }\end{array}$ & $\begin{array}{c}\text { Current } \\
\text { density } \\
\text { for the } \\
\text { third } \\
\text { bonding } \\
\mathbf{( A / m 2 )}\end{array}$ & $\begin{array}{c}\text { Current } \\
\text { density } \\
\text { for the } \\
\text { fourth } \\
\text { bonding } \\
\text { (A/m2) }\end{array}$ & Current(A) \\
\hline $\begin{array}{c}\text { Air } \\
\text { terminal } \\
\text { on the } \\
\text { main } \\
\text { frame }\end{array}$ & - & - & - & - & 1.49E+05 \\
\hline Row1 & $1 . \mathrm{E}+06$ & $4 . \mathrm{E}+03$ & $6 . \mathrm{E}+04$ & $2 . \mathrm{E}+06$ & $2 . \mathrm{E}+04$ \\
\hline Row2 & $7 . \mathrm{E}+05$ & $2 . \mathrm{E}+04$ & $7 . \mathrm{E}+04$ & $9 . \mathrm{E}+05$ & $9 . \mathrm{E}+03$ \\
\hline Row3 & $6 . \mathrm{E}+05$ & $2 . \mathrm{E}+04$ & $1 . \mathrm{E}+04$ & $6 . \mathrm{E}+05$ & $6 . \mathrm{E}+03$ \\
\hline Row4 & $2 . \mathrm{E}+05$ & $1 . \mathrm{E}+04$ & $5 . \mathrm{E}+03$ & $7 . \mathrm{E}+05$ & $5 . \mathrm{E}+03$ \\
\hline Row5 & $1 . \mathrm{E}+05$ & $5 . \mathrm{E}+03$ & $1 . \mathrm{E}+03$ & $6 . \mathrm{E}+04$ & $1 . \mathrm{E}+03$ \\
\hline Row6 & $3 . \mathrm{E}+05$ & $2 . \mathrm{E}+02$ & $2 . \mathrm{E}+03$ & $5 . \mathrm{E}+04$ & $2 . \mathrm{E}+03$ \\
\hline Row7 & $6 . \mathrm{E}+04$ & $1 . \mathrm{E}+03$ & $7 . \mathrm{E}+03$ & $3 . \mathrm{E}+04$ & $5 . \mathrm{E}+02$ \\
\hline Row8 & $7 . \mathrm{E}+03$ & $7 . \mathrm{E}+02$ & $5 . \mathrm{E}+02$ & $1 . \mathrm{E}+04$ & $1 . \mathrm{E}+02$ \\
\hline Row9 & $3 . \mathrm{E}+03$ & $2 . \mathrm{E}+04$ & $3 . \mathrm{E}+02$ & $2 . \mathrm{E}+03$ & $1 . \mathrm{E}+02$ \\
\hline Row10 & $2 . \mathrm{E}+04$ & $3 . \mathrm{E}+04$ & $1 . \mathrm{E}+03$ & $8 . \mathrm{E}+04$ & $7 . \mathrm{E}+02$ \\
\hline Row11 & $5 . \mathrm{E}+04$ & $8 . \mathrm{E}+02$ & $1 . \mathrm{E}+04$ & $1 . \mathrm{E}+05$ & $8 . \mathrm{E}+02$ \\
\hline Row12 & $4 . \mathrm{E}+05$ & $4 . \mathrm{E}+03$ & $1 . \mathrm{E}+03$ & $5 . \mathrm{E}+05$ & $5 . \mathrm{E}+03$ \\
\hline Row13 & $1 . \mathrm{E}+05$ & $4 . \mathrm{E}+03$ & $3 . \mathrm{E}+04$ & $3 . \mathrm{E}+05$ & $2 . \mathrm{E}+03$ \\
\hline Row14 & $3 . \mathrm{E}+05$ & $1 . \mathrm{E}+04$ & $1 . \mathrm{E}+04$ & $3 . \mathrm{E}+05$ & $4 . \mathrm{E}+03$ \\
\hline Row15 & $3 . \mathrm{E}+05$ & $4 . \mathrm{E}+04$ & $2 . \mathrm{E}+04$ & $4 . \mathrm{E}+05$ & $4 . \mathrm{E}+03$ \\
\hline Row16 & $5 . \mathrm{E}+05$ & $6 . \mathrm{E}+04$ & $2 . \mathrm{E}+04$ & $5 . \mathrm{E}+05$ & $5 . \mathrm{E}+03$ \\
\hline
\end{tabular}

When current is injected on the air terminal, the glass façade will take $(5.96 \mathrm{E}+04) /(1.5 \mathrm{E}+005) \approx 39.7 \%$ of the current. 


\section{B. Scenario II}

In the second scenario, the lightning current is injected into the top of the façade as illustrated in the Fig. 7.

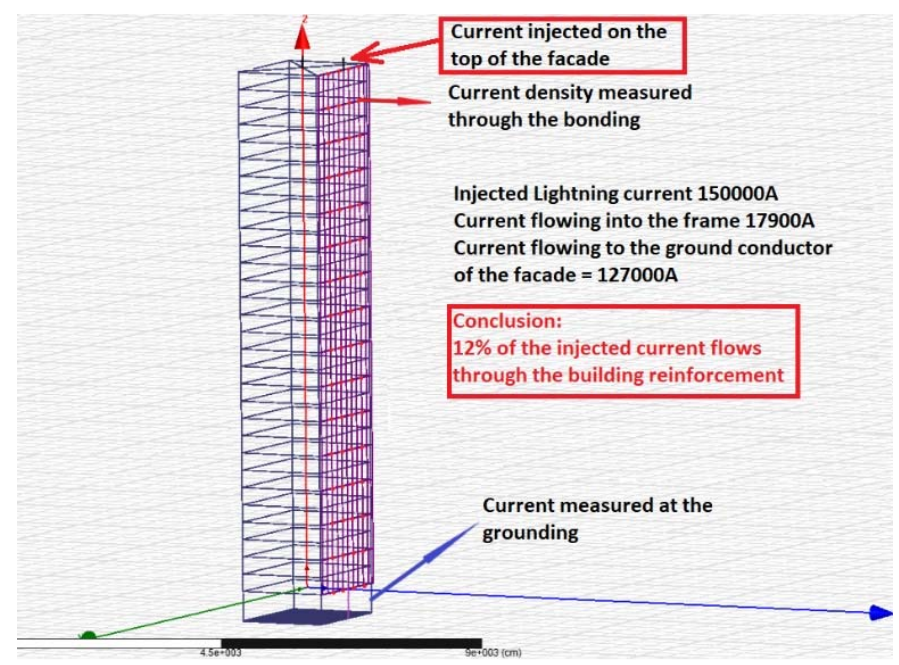

Figure 7. Current injected on top of the facade as in Scenario II [3]

TABLE II. SIMULATION RESULTS FOR SCENARIO II

\begin{tabular}{|c|c|c|c|c|c|}
\hline $\begin{array}{c}\text { Number } \\
\text { of } \\
\text { bonding } \\
\text { from } \\
\text { rooftop } \\
\text { to earth }\end{array}$ & $\begin{array}{c}\text { Current } \\
\text { density } \\
\text { for the } \\
\text { first } \\
\text { bonding } \\
\text { (A/m2) }\end{array}$ & $\begin{array}{c}\text { Current } \\
\text { density } \\
\text { for the } \\
\text { second } \\
\text { bonding } \\
\text { A/m2) }\end{array}$ & $\begin{array}{c}\text { Current } \\
\text { density } \\
\text { for the } \\
\text { third } \\
\text { bonding } \\
\text { (A/m2) }\end{array}$ & $\begin{array}{c}\text { Current } \\
\text { density } \\
\text { for the } \\
\text { fourth } \\
\text { bonding } \\
\text { (A/m2) }\end{array}$ & Current(A) \\
\hline $\begin{array}{c}\text { Air } \\
\text { terminal } \\
\text { on the } \\
\text { façade }\end{array}$ & - & - & - & - & $\mathbf{1 . 4 8 E + 0 5}$ \\
\hline Row1 & $1.90 \mathrm{E}+05$ & $3 . \mathrm{E}+05$ & $1 . \mathrm{E}+05$ & $1 . \mathrm{E}+05$ & $3.29 \mathrm{E}+03$ \\
\hline Row2 & $1.12 \mathrm{E}+04$ & $3 . \mathrm{E}+04$ & $1 . \mathrm{E}+05$ & $1 . \mathrm{E}+04$ & $7.67 \mathrm{E}+02$ \\
\hline Row3 & $7.74 \mathrm{E}+03$ & $2 . \mathrm{E}+04$ & $9 . \mathrm{E}+03$ & $5 . \mathrm{E}+03$ & $1.92 \mathrm{E}+02$ \\
\hline Row4 & $7.78 \mathrm{E}+02$ & $2 . \mathrm{E}+04$ & $6 . \mathrm{E}+03$ & $3 . \mathrm{E}+04$ & $2.60 \mathrm{E}+02$ \\
\hline Row5 & $2.58 \mathrm{E}+03$ & $2 . \mathrm{E}+03$ & $2 . \mathrm{E}+03$ & $8 . \mathrm{E}+02$ & $3.65 \mathrm{E}+01$ \\
\hline Row6 & $5.93 \mathrm{E}+03$ & $2 . \mathrm{E}+02$ & $9 . \mathrm{E}+02$ & $1 . \mathrm{E}+03$ & $4.12 \mathrm{E}+01$ \\
\hline Row7 & $3.87 \mathrm{E}+03$ & $3 . \mathrm{E}+02$ & $8 . \mathrm{E}+02$ & $1 . \mathrm{E}+03$ & $3.10 \mathrm{E}+01$ \\
\hline Row8 & $1.18 \mathrm{E}+03$ & $1 . \mathrm{E}+02$ & $3 . \mathrm{E}+02$ & $2 . \mathrm{E}+03$ & $1.97 \mathrm{E}+01$ \\
\hline Row9 & $9.72 \mathrm{E}+02$ & $2 . \mathrm{E}+04$ & $8 . \mathrm{E}+01$ & $7 . \mathrm{E}+02$ & $9.51 \mathrm{E}+01$ \\
\hline Row10 & $2.81 \mathrm{E}+03$ & $3 . \mathrm{E}+03$ & $3 . \mathrm{E}+02$ & $1 . \mathrm{E}+04$ & $8.80 \mathrm{E}+01$ \\
\hline Row11 & $6.90 \mathrm{E}+03$ & $5 . \mathrm{E}+02$ & $4 . \mathrm{E}+03$ & $1 . \mathrm{E}+04$ & $1.23 \mathrm{E}+02$ \\
\hline Row12 & $4.68 \mathrm{E}+04$ & $1 . \mathrm{E}+03$ & $1 . \mathrm{E}+03$ & $7 . \mathrm{E}+04$ & $5.78 \mathrm{E}+02$ \\
\hline Row13 & $7.56 \mathrm{E}+03$ & $4 . \mathrm{E}+03$ & $1 . \mathrm{E}+04$ & $4 . \mathrm{E}+04$ & $2.95 \mathrm{E}+02$ \\
\hline Row14 & $9.97 \mathrm{E}+04$ & $1 . \mathrm{E}+04$ & $1 . \mathrm{E}+04$ & $6 . \mathrm{E}+04$ & $9.35 \mathrm{E}+02$ \\
\hline Row15 & $1.89 \mathrm{E}+05$ & $3 . \mathrm{E}+04$ & $4 . \mathrm{E}+04$ & $2 . \mathrm{E}+05$ & $2.19 \mathrm{E}+03$ \\
\hline Row16 & $5.02 \mathrm{E}+05$ & $7 . \mathrm{E}+04$ & $2 . \mathrm{E}+04$ & $1 . \mathrm{E}+06$ & $8.92 \mathrm{E}+03$ \\
\hline Total current flowing through bonding(A) & $\mathbf{1 . 7 9 E + 0 4}$ \\
\hline
\end{tabular}

The current flowing into main frame through bonding is $(1.79 \mathrm{E}+04) /(150000) \approx 12 \%$ of the injected current.

\section{DISCUSSIONS AND CONCLUSIONS}

In the first scenario, the lightning current is injected into the air terminal at the top center of the building model. There exists a continuous path to ground through the reinforcement rods and the facade structure as the frames are electrically continuous. The current conducted through the air terminal takes the path to ground through the facade as well as the down conductor (Steel reinforcement). The current path is divided between the facade and the down conductor.

In the second scenario, the lightning current is injected on the air terminal on the façade at the edge of the building. Here again the façade and the main reinforcement structure are electrically bonded. There is more current flowing along the facade as they are electrically continuous and due to the 'skin effect'.

The simulation results necessitate the need to investigate the ability of the façade frames to conduct lightning current. The results clearly show that, in the event where an electrical ground exists for the façade structure, the glass façade structure conducts significant lightning current to ground. However, glass façade structures are currently not designed to conduct lightning current. Design considerations used in the construction of glass façade structures include resistance to weathering, fire, heat and sound [6], [7]. The conduction of lightning current to ground through the glass façade frame structure when the façade is independently grounded possess an enormous safety threat to life, the façade structure and the entire building.

High transient lightning current conduction in the glass façade frame generates heat in the façade frames. However, the thermal insulation fitted in glass façade structures for tall buildings are mainly rated for atmospheric temperatures and the heating of the frames by the sun. The thermal insulation helps to improve the energy efficiency of the building. These insulation materials cannot cope with the high heating effect and subsequent temperature rise due to the conduction of the lightning current in the glass façade frames [7], [8], [9], [10].

A significant amount of glass façade frames is made from aluminium [11]. Corrosion is a major challenge with aluminium alloys. Aluminium is more prone to corrosion than steel and copper in the galvanic series. Direct lightning strikes to a tall building with glass façade architecture can result in defects and mechanical failures of the façade frame, a condition which can initiate corrosion pits on aluminium alloys. The conductive nature of glass façade frames and the possibility of lightning side strikes in tall buildings makes such defects possible since the facade frames can serve as a point of entry for lightning current [12]. Also, corrosion of the glass façade frames can occur due to galvanic different metals as is the case in practice since the façade frames are bonded to the loadbearing element of the tall buildings though copper wires.

Even though corrosion related problems do not pose any significant threat to the LPS of the building, the corrosion on the glass façade structure presents a significant safety risk to the buildings, its occupants and the public. Since the frame form the support for the glazing panels, corrosion can result in 
the weakening of the support of the glass façade structure. Such an incidence can cause a glazing unit to fall from a height. This represents a risk to all users of the building both internal and external. Additionally, the corrosion of the glass façade frames of a tall building will require a substantial amount of site work to rectify such a defect especially if the corrosion occurs at a height. Such a work, though expensive, is unavoidable due to the significant danger posed by a weakened glass façade support at a height of a tall building.

There are also other challenges that must be considered because of the conduction of lightning current through the glass façade frames. The glass façade frames in practice, are not electrically continuous since it is impractical to have them in such lengths. The insulation materials used in the installation of glass façade profile units are not to gain electrical insulation of the units. They are employed to seal the gaps present due to the modular installation of the façade profile units, establish thermal insulation and to allow for the contraction and expansion of the thermally conductive frame structures because of temperature [9], [13], [14]. Since the installation materials are not graded to provide insulation against lightning current, there is a possibility of lightning current flashover that can bridge the electrical gap between the individual façade profile units. In addition, the magnitude of electric field associated with lightning current can cause a breakdown of the insulation present between the façade structure and physical earth due them to relatively short distance between them in most building designs. These two scenarios establish an electrically continuous path from the air-termination system of the building, through the glass façade structure to ground and allows for the conduction of lightning current through the glass façade structure.

The results obtained in this research indicate that the present implementation of the current Lightning Protection Standard may not sufficiently protect tall buildings with glass façade architecture from lightning strikes. The result indicates that in the instance of a lightning strike, the glass façade frames conduct a significant amount of lightning current to ground when there exists an independent electrical path to ground through the façade frames. An electrical path to ground through the façade profiles can be established when a person touches the frame of the glass façade structure in the instance of a direct lightning strike on the building. Even though the various façade profile units are not electrically connected, the emphasis of thermal insulation instead of electrical insulation presents a situation where the gaskets and thermal insulation can breakdown under the electric field generated by lightning. Such a situation presents a significant risk to life due to the possibility of harmful touch voltage. In addition, the closeness of the entire glass façade structure to the physical earth as seen in many tall buildings with glass façade architecture increases the possibility of harmful flash overs.
The conduction of lightning current in the glass façade profile frames and its implication to the building structure, life and property necessitates the need to consider the incorporation of glass façade structure in the LPS of tall buildings with glass façade architecture. Since the overall aim of lightning protection of buildings is to the reduce the risk to life, property and buildings because of lightning, there is the need to develop special lightning protection measures for such buildings that incorporate the façade structure into the building's LPS. There is the need to address the electrical discontinuity of the façade profiles in order to incorporate the glass façade structure into the LPS of buildings. The materials used in constructing façade profiles must not be selected based on supplier's preference but appropriately rated to withstand and safely conduct lightning current. In conclusion, this paper has shown that the current Standard for lightning protection of buildings may not be effective for buildings with glass façade architecture and the authors recommend further research and development to standardize façade components and the connecting methods necessary to achieve a more effective protection system for the lightning protection of tall buildings with glass façade architecture.

\section{REFERENCES}

[1] Illustration by Ramboll Façade Engineering

[2] R. Afghani Khoraskani, Advanced Connection Systems for Architectural Glazing, 1st ed. Cham: Springer International Publishing, 2015.

[3] Illustration by Ziyang Peng \& HK Agyemang, University of Strathclyde

[4] H. KG, "HUECK Trigon 60 | HUECK Aluminium Systems", Hueck.com, 2017. [Online].

Available:http://www.hueck.com/alusys/de/en/home/products/facadesystems/hueck-trigon-60.html. [Accessed: 31-Mar- 2017].

[5] CWCT Curtain Wall Installation Handbook, 1st ed. Bath: Centre for Window and Cladding Technology, 2001, pp. 1-34.

[6] "Facades - Saint-Gobain Glass UK", Uk.saint-gobain-glass.com, 2016. [Online].

Available: http://uk.saint-gobain-glass.com/trade-customers/facades. [Accessed: 1- Feb- 2017].

[7] NWS Lightning Fatalities", Lightningsafety.noaa.gov, 2017. [Online]. Available:http://www.lightningsafety.noaa.gov/fatalities.shtml. [Accessed: 31- Mar- 2017].

[8] Furse.[Online]. Available:http://wwwpublic.tnb.com/eel/docs/furse/BS_EN_IEC_62305_standard_series.pdf. Accessed: Feb. 2, 2017.

[9] BS EN 62305-2:2012 Protection against lightning Part 2: Risk management. 2012.

[10] Joseph R. Dwyer, Martin A. Uman, The physics of lightning, Physics Reports, Volume 534, Issue 4, 30 January 2014, Pages 147-241

[11] [Online]. Available: http://www.elect.mrt.ac.lk/HV_Chap3.pdf. Accessed: Mar. 1, 2016.

[12] "Overview of Global Lightning Protection Codes and Standards National Lightning Safety Institute", Lightningsafety.com, 2017. [Online]. Available: http://lightningsafety.com/nlsi_lhm/standards.html. [Accessed: 31- Mar- 2017].

DEHN, Lightning Protection Guide, 3rd update., vol. 127, no. 12. DEHN + SÖHNE, 2014.. 